\title{
ACADEMIC APPROACH ABOUT E-LEARNING MODULES FROM THE TEACHER/STUDENT PERSPECTIVE AT THE NATIONAL UNIVERSITY MAYOR DE SAN MARCOS, LIMA-PERÚ
}

\author{
Roxanna Saldarriaga \\ Universidad Nacional Mayor de San Marcos, Lima, (Perú). \\ E-mail: roxanna.saldarriaga@unmsm.edu.pe ORCID: https://orcid.org/0000-0002-1823-2470
}

Hugo Vega

Universidad Nacional Mayor de San Marcos, Lima, (Perú). E-mail: hvegah@unmsm.edu.pe ORCID: https://orcid.org/0000-0002-4268-5808

\begin{abstract}
Giro Rodriguez
Universidad Nacional Mayor de San Marcos, Lima, (Perú). E-mail: crodriguezro@unmsm.edu.pe ORCID: https://orcid.org/0000-0003-2112-1349

Percy De La Gruz

Universidad Nacional Mayor de San Marcos, Lima, (Perú). E-mail: pdelacruzv@unmsm.edu.pe ORCID: https://orcid.org/0000-0002-4943-7620
\end{abstract}

\section{Citación sugerida:}

Saldarriaga, R., Vega, H., Rodriguez, C., y De La Cruz, P. (2021). Academic approach about E-learning modules from the teacher/student perspective at the National University Mayor de San Marcos, Lima-Perú. 3C TIC. Cuadernos de desarrollo aplicados a las TIC, 10(3), 121-139. https://doi.org/10.17993/3ctic.2021.103.121-139 


\section{ABSTRACT}

The article examines the teacher/student perspective about E-learning modules that could be applied to the courses of the Administration career at the Universidad Nacional Mayor de San Marcos based on 2 methodologies that project a better vision of teaching. To carry out these methodologies, it is necessary to review the results obtained in a survey to determine the factors that influence student learning through the proposed E-learning modules. As a result, 6 factors were obtained to validate whether these E-learning modules are suitable for Flipped Classroom and B-learning Methodologies. It is important to highlight that due to the Covid-19 pandemic, different teaching methods have been chosen virtually, and the evaluation carried out; it was determined that $40 \%$ of the students who are virtually taking their courses feel satisfied and eager to continue studying using different technological tools.

\section{KEYWORDS}

E-learning, Flipped Classroom, Blended, ICT, Cloud Computing, Academic approach. 


\section{INTRODUCTION}

This paper is possible to observe various research where the importance of using E-learning platforms for the learning process; this leads us to analyze the impact on teachers and undergraduate students of the administration career of the Universidad Nacional Mayor de San Marcos.

It has been reflected that the lack of motivation influences enormously. Not having the necessary tools is a key factor to not continue under this methodology, such as the lack of equipment, its failures, the few skills of the user, the lack of training, connectivity, and everything related to the digital environment, generates impotence in students and leads them to the day. In a technological world that is changing day by day, it is basic to know and master it (Escobar, 2015).

A survey was conducted based on ICT knowledge and E-learning methodologies resulting in only 40\% being motivated to take their courses virtually.

After the Covid-19 pandemic, it has been mandatory to look for different teaching alternatives in a non-face-to-face way, even using improvised digital tools to meet the academic objective. Motivation is fundamental for proper teaching.

As an objective of this research, we must validate the factors that influence this teaching method and apply the best educational methodology for implementing digital didactic modules as a learning strategy.

\section{PREVIOUS CONCEPTS}

\subsection{IMPORTANCE OF E-LEARNING}

Clark and Mayer (2016) tell us that technology, unlike the human nervous system, can easily deliver more sensory data because cognitive systems are limited by various information competing for this limited capacity. The student should choose the one that suits him best. 
In addition, it suggests training and helping those who need it and more if they know the case and want to achieve change, it is essential to design environments where experiences are created since that is where change is encouraged.

Some benefits considered are adapting the student's learning itinerary, the combination of collaborative activities with self-directed study, and the quality of teaching since it has the same level.

According to Ghirardini (2014), cognitive, interpersonal, and psychomotor skills development training programs, within the domain, more interactive E-learning activities could be applied to thinking skills through interactive games and feedback.

\subsection{BLENDED LEARNING}

The difficulties generated by this model and the defects generated by a dominant economic factor are 2 very influential perspectives in many projects. Bartolomé (2004) is the same educational training, but at a distance powered by technology.

E-learning has shown its effectiveness for certain approaches, but it carries some limits since not all the population is prepared.

We have the following solutions applied in important Spanish and Latin American institutions using E-learning:

- Work overload.

- Low-cost tutors.

- A great weight of learning in materials that do not require human support.

According to what has been seen above, it has been a reason to open up the Blended learning concept as a response to face-to-face institutions since not all people approve of E-learning 100\%. 
Some topics require face-to-face evaluation; therefore, the most optimal thing is that combined learning is implemented to be done virtually and training in person. "Blended learning includes face-to-face classroom practices that are combined with computer-mediated activities regarding content and delivery" (Shankarwader, 2019).

This modality has more and more followers to be an alternative of possibilities open to combining personal and professional life (Aznar, Cáceres \& Romero, 2019).

\subsection{FLIPPED CLASSROOM}

Better known as Inverse Methodology, students have access to learning content based on the topics they will have in class, such as materials, video lectures, etc., as part of the teaching objective. In this way, they will interact in the classroom with the previously reviewed cooperative learning methods or group work (Yilmaz, 2017).

It is understood that to ensure its effectiveness, students must know before face-to-face work.

Moreover, preparation for E-learning in the student can be a factor to ensure satisfaction and motivation in the FG model.

According to the author, the Flipped Classroom, or Inverted Classroom (FG), is a different approach since both works inside the class and outside.

This model has demonstrated higher academic performance than traditional reading (LB) based learning, mainly by developing different technological resources such as Google Drive, YouTube, or Google Classroom.

The main objective has been to evaluate the effectiveness of a Flipped Classroom methodology in the performance of students. 
"It has been argued that future studies should have greater methodological rigor, a standardized HR format, and use assessment tools that evaluate the higher cognitive learning process rather than an exam" (Oliván-Blázquez et al., 2019).

\subsection{ICT IN HIGHER EDUCATION}

Baelo and Cantón (2009) evidences several opinions of "technology" such as, for example, Haag (2004), who said that "information technologies are composed of any computer-based tool and that people use to work with information, support information and process information needs". The author also mentions Majó and Marqués (2002), who refer to 3 fields: telecommunications, computer science, and image and sound technologies. It also includes Cabero (2000) and Ortega (1997), who made the distinction between conventional technologies (based on speech, drawing, painting), new technologies (audiovisual resources), and advanced technologies (such as computer software design or animation).

Within this process, the Technologies of Information and Communications (ICT) become more important, providing organizational flexibility of these teachings. Hilario et al. (2021) mention that ICT supports decision-making as an integration of business information. Córdova et al. (2020) mention that one of the ICT tools that companies have been incorporating to optimize the processes, especially those binding to the documentary procedures, uses the digital signature, especially now in Pandemic. Salas, Vega and Rodriguez (2021) mention the main contributions of ICT to take them as a business reference. Martínez et al. (2020) state that proximity m-marketing with beacon devices is a successful strategy for reaching customers accordingly.

"They have also been involved in all fields of education to help administrative processes, a new group of higher education people, and development of methodologies development methodologies" (Baelo \& Cantón, 2009; Gayle, Tewarie, \& White, 2003).

According to Baelo and Cantón (2009), some of the benefits of ICT inclusion are the ease of access to information and the variety of information available, the parameters of reliability and speed of data 
processing, the feedback possibilities they offer, their great interactivity and development of flexible spaces for learning and to optimization of the organization and development of teaching and research activities.

Measures to be developed according to the author:

- The training, technical and pedagogical training of the teacher.

- Motivation and recognition.

- Investment.

\subsection{EDUCATIONAL SERVICES THROUGH THE USE OF CLOUD COMPUTING TECHNOLOGIES}

Cloud Computing is in full evolution and maturity to be used in the university academic field.

Cloud Computing is a model for enabling network access from a shared pool of configurable computing resources (networks, servers, storage, applications, and services) that can be quickly provided and easily removed (Yrigoyen \& Torres, 2011).

Table 1. Academic cloud resources.

Source: (Yrigoyen \& Torres, 2011).

\begin{tabular}{|c|}
\hline Academic Community \\
Services \\
Educational \\
$\Uparrow$ \\
Applications \\
$\Uparrow$ \\
Platform \\
$\Uparrow$ \\
Infrastructure \\
Academic Cloud \\
Public \\
\hline
\end{tabular}




\subsection{STUDENT MOTIVATION AND COMMITMENT IN VIRTUAL EDUCATION}

Gutierrez and García (2016) tell us that online education is truly an optimal means to familiarize ourselves with technologies, especially developing competencies autonomously and progressively. Unfortunately, as time goes on, students tend to become less motivated and disinterested.

That is why hybrid or virtual training proposals must be of the highest quality using game-based learning techniques:

- Remain in constant change within the online training process.

- Determine the motivational factors to reinforce.

- Provide proposals that promote virtual learning.

It is important to include multimedia designs in virtual learning environments. It is part of the interaction between the teacher and the student using digital materials to reach the objectives set through discussion spaces and research groups for common topics (Manrique \& Uc, 2020).

Another way to motivate the student is through Gamification, taking advantage of virtual tools, playful elements could be included in the educational context under this modality.

Torres-Toukoumidis, Romero-Rodríguez, and Pérez-Rodríguez (2017) says:

Although there is no single conceptualization regarding gamification in the education sector, in all of the students are presented in the face of an experience that tends to be immersive, changing principles provided by traditional education to new parameters of learning, based on motivation and social identification, applying game mechanisms to make the pedagogical process more attractive, and ultimately effective. 


\subsection{E-LEARNING IN PANDEMIC COVID-19}

Ntshwarang, Malinga, and Losike-Sedimo (2021) mention that, in the wake of the pandemic, the University of Botswana in India had to opt for Moodle and Blackboard Learn (BBL) tools while Moodle was less expensive for its constructivist social approach, BBL had improvements in interactive learning such as blogs, forums, etc. This caused many institutions to opt for Moodle in all their faculties and cities.

"It is observed that E-learning emphasizes the quality and effective presentation of information" it is becoming difficult to maintain educational standards due to the limitations of finances, infrastructure, and other resources, including skilled and experienced human power (Trakru \& Jha, 2019).

Likewise, Radha et al. (2020) made a study of students from different schools and universities in India, where they validated that E-learning provides rapid growth proving to be the best in all sectors, especially in Education during this pandemic, considering that the use of a desktop computer, laptop or smartphones, and internet, form an important component in this new field.

Table 2. Positivity towards E-learning.

\begin{tabular}{|c|c|c|}
\hline Classification & Surveyed & Percentages \\
\hline Yes & 133 & 76 \\
\hline No & 12 & 6,86 \\
\hline maybe & 30 & 17,14 \\
\hline Total & 175 & 100 \\
\hline
\end{tabular}

Source: (Radha et al., 2020).

Educational institutions and the government must strive to improve distance education and maintain an adequate E-learning infrastructure supporting all teachers through training and workshops to increase their knowledge, be aligned with technological knowledge, and contribute to the desired learning. Having the software and hardware of the E-learning infrastructure is the main factor in achieving success (Garad, Al-Ansi \& Qamari, 2021). 
However, for Huanca et al. (2020), it is still a failure to have these requirements at the national level because it is not applicable for provincial students; this remains a great challenge that will have to be solved gradually by educational agents such as governments, universities, civil society and teachers.

\section{METHODOLOGY}

This research seeks to know the incidence of the variables "Motivation for IT in Education" and "Usefulness of ICT in E-learning Modules", so, depending on the type of research, the present is "correlational", since it measures the degree of association between two variables, as it appears in this research. The correlation will help us determine the feasibility of implementing E-learning modules to strengthen teaching.

\subsection{UNIT OF ANALYSIS}

It is made up of the students of the Administration career of the UNMSM, who will be applied to a survey to identify the importance of ICT in Education to apply E-learning teaching methods.

\subsection{POPULATION AND SAMPLE}

The Population will be the students that make up the career of Administration of the UNMSM. It has been considered taking the sample to students of the 7 th cycle to the 10 th cycle since they carry courses related to IT from that year. To check the number of students, the average number of vacancies in the admission exam (200) has been used with a dropout rate per cycle of $-10 \%$.

Table 3. The population of respondents.

Source: own elaboration.

\begin{tabular}{|c|c|}
\hline Cycle & Quantity \\
\hline VII & 106 \\
\hline VIII & 95 \\
\hline IX & 86 \\
\hline X & 80 \\
\hline Total & $\mathbf{3 6 7}$ \\
\hline
\end{tabular}


To calculate the known sample size, we use the following:

$\mathrm{n}=$ The sample size

$\mathrm{N}=$ Population size 185

$\sigma=$ Population standard deviation 0.5

$\mathrm{Z}=$ Confidence levels 1.96

e $=$ Acceptable sample error limit 5\% (0.05)

$$
\begin{gathered}
n=\frac{367 * 0.5^{2} * 1.96^{2}}{(367-1) 0.05^{2}+0.5^{2} * 1.96^{2}} \\
n=\frac{352.4}{1.9}=185
\end{gathered}
$$

If I survey 185 people, $95 \%$ of the time, the data you want to measure will be in the range $\pm 5 \%$ concerning the data you observe in the survey.

\subsection{DATA COLLECTION}

The interview research methodology was used as the main tool of the questionnaire.

To evaluate the research variables, we used an 8-question questionnaire.

\subsection{PROCEDURE}

For the process of distribution and data collection, the following steps will be considered:

- Prepare a list of questions asked about the approach and factors to implement an E-learning module. 
- Prepare invitations to the students of the administration career of the UNMSM to send it digitally with the approval of the dean of the faculty.

- Wait for confirmation to start receiving student-filled surveys.

\subsection{DATA RELIABILITY}

To validate the instrument, Cronbach's alpha will be used to review professionals in IT Management and Education.

Cronbach's alpha is interpreted: the more significant the alpha value is close to 1 , the greater the consistency of the items analyzed. So, if the alpha value is greater than 0.7 , the instrument is accepted.

\subsection{ANALYSIS AND INTERPRETATION OF DATA}

It has been considered for the statistical analysis:

- Reliability test using Cronbach's Alpha.

- Analysis of results.

- Discussion of results.

\section{RESULTS}

The following analysis was carried out based on questions related to ICT use in Education and student motivation to determine the approach and implementation factors of E-learning modules in conjunction with the best methodology to specify the student's knowledge.

It has been seen that the Flipped Classroom or inverted classroom is a good methodology to carry a good pace of learning since, under this modality, the student will be able to investigate and solve their courses through these modules as activities before the start of class, so that later, with the teacher in a synchronous way they can validate the activities carried out. 
On the other hand, B-learning or Blended is a semi-face-to-face methodology, could be used once returned to face-to-face classes post Covid-19 since this methodology can take activities using the E-learning modules synchronously or asynchronously.

\subsection{RELIABILITY ANALYSIS}

To validate the instrument's reliability, the reliability analysis was performed using Cronbach's Alpha based on 185 students surveyed.

Table 4. Interpretation of Alpha Cronbach reliability.

\begin{tabular}{|c|c|}
\hline Value of the coefficient & Interpretation \\
\hline$>0,9$ & Excellent \\
\hline Between $0.9-0.8$ & Well \\
\hline Between $0.8-0.7$ & Acceptable \\
\hline Between $0.7-0.6$ & Weak \\
\hline Between $0.6-0.5$ & Poor \\
\hline$<0.5$ & Not acceptable \\
\hline
\end{tabular}

Source: (Frías-Navarro, 2020).

Table 5. Cronbach's alpha reliability statistics.

\begin{tabular}{|c|c|}
\hline Alfa de Cronbach & Number of elements \\
\hline 0.924 & 8 \\
\hline
\end{tabular}

Source: own elaboration.

The value of the coefficient we have obtained is 0.924 , which is interpreted as good reliability.

\section{CONCLUSIONS}

As a result of the analysis of the problem of the lack of motivation to use virtual learning tools at the UNMSM through the surveys carried out, it is concluded that only $40 \%$ of the students who take several courses in a virtual form within their curricular mesh feel comfortable with this type of methodology since it requires an entirely didactic and easy to handle system and most importantly, to have at their disposal 
a quality software and hardware to be able to carry the teaching subject; to improve this percentage we evaluate the type of platform.

E-learning will be used to take advantage of the changes that are currently taking place to explore all the resources necessary to invest in an excellent virtual tool, and after the analysis made to the data obtained in the surveys carried out, it was obtained that the factors that influence virtual teaching are the following.

- ICT is necessary for any area of the student and more now because of the pandemic.

- Quality E-learning platforms are practical and dynamic means to obtain new knowledge.

- Technological attitude, students can acquire new knowledge through new learning methodologies using virtual media. It has been seen that it is always necessary to change learning strategies.

- Continuous training, teachers, students, and administrative staff must be constantly trained and updated to correctly use E-learning tools and be aligned with the latest educational, technological trends.

- The virtual platforms must be equipped for laptops, PGs, mobile devices, or tablets and be portable.

- Good Software and Hardware for a virtual educational infrastructure is the best long-term investment.

The methodology used for the excellent use of E-learning platforms, according to this research, is the Flipped Classroom (Inverted Classroom) and B-learning (Blended or Semi face-to-face); the latter will be necessary when the face-to-face classes are retaken. The teacher may determine to apply it synchronously or asynchronously as appropriate.

We are entering a new world where Technology imposes itself on our habits of life, mainly because it is already a necessity. We must be open to change and allow new creations and be part of them. 


\section{REFERENCES}

Aznar, I., Cáceres, M. del P., \& Romero, J. M. (2019). Digital competence of an E-learning tutor: An emerging model of good teaching practices in ICT. Linguagem e Tecnologia, 12(3), 49-68. https:// digibug.ugr.es/handle/10481/58893? show=full

Baelo, R., \& Cantón, I. (2009). Las tecnologías de la información y la comunicación en la educación superior. Descriptive and review study. Revista Ibero Americana de Educación, 50(7), 1-12. https:/ / doi. org/10.35362/rie5071965

Bartolomé, A. R. (2004). Blended Learning. Basic concepts. Pixel-Bit: Revista de Medios y Educación, 23, 7-20. https://idus.us.es/handle/11441/55455

Cabero, J. (2000). Las nuevas tecnologías de la información y la comunicación: aportaciones a la enseñanza. En: Cabero, J., Nuevas Tecnologías aplicadas a la educación. Síntesis, pp. 15-38. https:/ / dialnet. unirioja.es/servlet/libro?codigo $=12009$

Glark, R., \& Mayer R. (2016). E-learning and the Science of Instruction. Proven Guidelines for Consumers and Designers of Multimedia Learning (4th ed.). John Wiley \& Sons Inc.

Córdova, J., Vega, H., Rodriguez, G., \& Escobedo, F. (2020). Digital signature based on asymmetric cryptography for generation of medical history. 3C Tecnología. Glosas de innovación aplicadas a la pyme, 9(4), 65-85. https://doi.org/10.17993/3ctecno/2020.v9n4e36.65-85

Escobar, E. A. (2015). Relación entre el uso de técnicas de estudio y la deserción de estudiantes que tomaron asignaturas E-learning como apoyo a programas presenciales de la Institución Universitaria Pascual Bravo en el semestre II de 2013 y semestre I de 2014. http:/ / hdl.handle.net/20.500.12749/2746

Frías-Navarro, D. (2020). Notes of internal consistency of the scores of a measuring instrument. The University of Valencia. 
Garad, A., Al-Ansi, A. M., \& Qamari, I. N. (2021). The role of E-learning infrastructure and cognitive competence in distance learning effectiveness during the COVID-19 Pandemic. Furnal Ilmiah Pendidikan, 40(1). https://journal.uny.ac.id/index.php/cp/article/view/33474

Gayle, D., Tewarie, B., \& White, A. Q. Jr. (2003). Challenges to University Governance Structures. ASHE-ERIC Higher Education Report, 30(1).

Ghirardini, B. (2014). E-learning methodologies. FAO.

Gutierrez, R., \& García, A. (2016). How to improve student quality, motivation, and commitment in virtual education?

Haag, S., Cummings, M., \& McCubbrey, D. J. (2004). Management information systems for the information age (4 $4^{\mathrm{a}}$ ed.). McGraw-Hill.

Hilario, M., Esenarro, D., Vega, H., \& Rodríguez C. (2021). Integration of the enterprise information to facilitate decision making. Fournal of contemporary issues in business and government, 27(1).

Huanca, J., Supo, F., Sucari, R., \& Supo, L. (2020). The social problem of virtual university education in times of pandemic. Peru.

Majó, J., \& Marqués, P. (2002). The educational revolution in the internet age. Collection "Commitment to education". Cisspraxis.

Manrique, Y., \& Uc, C. (2020). Performance of multimedia design in integral learning in Primary Education. 3C TIC. Cuadernos de desarrollo aplicados a las TIC, 9(2), 17-39. https://doi.org/10.17993/3ctic.2020.92.17-39

Martínez, G., Vega, H., Rodriguez, C., \& Guzmán, Y. (2020). Proximity marketing through mobile application with beacon devices. 3C TIC. Cuadernos de desarrollo aplicados a las TIC, 9(4), 89-111. https://doi.org/10.17993/3ctic.2020.94.89-111 
Ntshwarang, P. N., Malinga, T., \& Losike-Sedimo, N. (2021). E-learning Tools at the University of Botswana: Relevance and Use under COVID-19 Crisis. Higher Education for the Future, 8(1), 142154. https://doi.org/10.1177/2347631120986281

Oliván-Blázquez, B., Masluk, B., Gascon, S., Fueyo, R., Alguilar-Latorre, A., Artola, I., \& Magallón, R. (2019). The use of flipped classroom as an active learning approach improves academic performance in social work: A randomized trial in a university. PLoS One, 14(4), e0214623. https://pubmed.ncbi.nlm.nih.gov/30947270/

Ortega, J. A. (1997). New technologies and school organization: eco-community proposal of structure and use of teaching aids and technologies. Grupo Editorial Universitario, pp. 203-222.

Radha, R., Mahalakshmi, K., Sathish, V., \& Saravanakumar, A. R. (2020). E-learning during Lockdown of Covid-19 Pandemic: A Global Perspective. International Fournal of Control and Automation, 13(4), 1088-1099. http://sersc.org/journals/index.php/IJCA/article/view/26035

Salas, G., Vega, H., \& Rodriguez, G. (2021). Contributions to the Technological Adoption Model for the Peruvian Agro-Export Sector. International fournal of E-Adoption (IfEA). https://doi. org/10.4018/IJEA.2021010101

Shankarwader, S. (2019). E-learning versus classroom training. International Research fournal of Engineering and Technology, 6(12). https://issuu.com/irjet/docs/irjet-v6i12288

Torres-Toukoumidis, Á., Romero-Rodríguez, L. M., \& Pérez-Rodríguez, M. A. (2017). Integrated Theoretical Model of Gamification in E-learning Environments (EMIGA). Revista Complutense de Educación, 29(1), 129-145. https://doi.org/10.5209/RCED.52117

Trakru, M., \& Jha, T. K. (2019). E-learning Effectiveness in Higher Education. International research fournal of Engineering and Technology (IRFET), 6(5). https://www.irjet.net/archives/V6/i5/ IRJET-V6I520.pdf 
Yilmaz, R. (2017). Exploring the role of e-learning readiness on student satisfaction and motivation in flipped classroom. Computers in Human Behaviour, 70, 251-260. https://doi.org/10.1016/j. chb.2016.12.085

Yrigoyen, M., \& Torres, C. (2011). Educational services through the use of Cloud Computing technologies. 
